\title{
Financial literacy and the use of financial services in Serbia
}

\section{Финансијска писменост и употреба финансијских услуга у Србији}

\author{
Slađana Barjaktarović Rakočević ${ }^{*}$ \\ University of Belgrade, Faculty of Organizational Sciences, Belgrade, Republic of Serbia, sladjana@fon.bg.ac.rs \\ Nela Rakić \\ University of Belgrade, Faculty of Organizational Sciences, Belgrade, Republic of Serbia, nela.rakic@fon.bg.ac.rs \\ Marina Ignjatović \\ University of Belgrade, Faculty of Organizational Sciences, Belgrade, Republic of Serbia, \\ marina.ignjatovic@fon.bg.ac.rs

\section{Milica Stevanović} \\ United Cloud, Belgrade, Republic of Serbia, stevanovic.m1993@gmail.com
}

\begin{abstract}
Financial services industry has always drawn a lot of attention, from possible investors, those who need financing, the government and general public. Globally, financial opportunities are becoming more attractive, but also more complex. The goal of this study is to analyze the use of financial services in Serbia. We argue that financial education and literacy are preconditions for the use of financial opportunities. Research has shown that people in Serbia are not well informed about how to make sound financial decisions. The reasons why people in Serbia do not use financial products requires to a greater extent and services special attention. In order to test the differences between people in terms of how well informed they are and which services they use and why, we conducted a survey. Our results show that people with salaries higher than 100,000 RSD are well informed but not motivated to invest. Individuals with middle income do not have enough trust and think that they are not well informed about different opportunities. Additionally, we found that men are better informed than women. This paper aims to provide an overview of the use of financial services in Serbia in order to improve financial decisionmaking processes and understand the different financial opportunities.
\end{abstract}

Keywords: financial literacy, awareness of financial products and services, financial decisions JEL classification: G20, G53

Сажетак: Индустрија финансијских услуга одувек привлачи велику пажњу потенцијалних инвеститора, зајмопримаца, државе и шире јавности. Генерално, финансијске услуге постају све атрактивније али и сложеније. Циљ ове студије јесте да анализира употребу финансијских услуга у Србији. Сматрамо да су финансијско образовање и финансијска писменост предуслови за коришћење финансијских могућности. Истраживања показују да већина људи у Србији није добро информисана око доношења квалитетних финансијских одлука. Потребно је посебно анализирати разлоге због којих људи у Србији не користе финансијске производе и услуге у већој мери. Како би утврдили разлике у погледу информисаности и употребе финансијских услуга, спровели смо упитник. Наши резултати показују да су људи који имају зараду већу од 100.000РСД боље информисани али недовољно мотивисани да инвестирају. Појединци са средњим нивоом примања немају довољно поверења и сматрају да нису добро информисани у погледу различитих могућности. Поред тога, резултати показују да су мушкарци боље информисани од жена. Циљ овог рада јесте да пружи преглед употребе финансијских услуга у Србији како би се

Corresponding author 
побољшао процес финансијског одлучивања и разумеле различите финансијске могућности. Кључне речи: финансијска писменост, познавање финансијских производа и услуга, финансијско одлучивање

JEЛ класификација: Г20, Г53

\section{Introduction}

The financial services industry is vast and highly diverse. The industry's scope comprises comprehensive areas like bank management (both commercial and investment banking), investment management (different forms of investment and pension funds), insurance companies, securities investments and brokerage companies, as main areas. This industry is equally important to both companies and individuals. Having in mind all the aforementioned areas, it is obvious why it is said that financial services industry is one of the main drivers of a country's economy. It serves as arena for payments, intermediation between savers and borrowers, risk transfer, liquidity etc., to mention just a few important roles financial services industry has. With those important roles come very strict and detailed legislative and regulatory practice for all the areas of financial services industry.

Financial services are also arena with very tremendous changes happening almost continually. The need for innovation is a must for all industries today, and financial services are not exception; on the contrary. Due to constant changes and innovations, financial services industry is reshaping the way it offers and distributes its services to customers. Those activities are not a one-time event, but constant urge for innovation "that will shape customer behaviors, business models, and the long-term structure of the financial services industry" (World Economic Forum, 2015).

When we talk about innovation in financial services industry, first we think of fintech innovation. Fintech (financial technologies) innovation refers to application of technologies in financial services industry. Therefore, Fintech combines financial services with technological development to help both individuals as well as all kind of business from start-ups to big companies. Fintech changes the way those categories use financial services. Thanks to mobile devices, Internet, software, cloud services etc., we do not use financial services traditionally anymore. Fintech brought us financial services in a faster, more convenient and improved manner.

Considering financial services in Serbia, there are all types of financial institutions that offer different financial services. But, the development of financial institutions is not equal, in the sense that some of the financial institutions, especially banks, are far bigger than others. If we take into consideration total financial assets financial institutions in Serbia manage, then the situation is as follows: banks hold $89,2 \%$ of total assets, insurance companies $6,6 \%$, financial leasing 2,3\%, voluntary pension funds $1 \%$ and investment funds 0,9\% (National Bank of Serbia, 2019; Republic of Serbia Securities Commission, 2019). It is obvious from those facts that Serbia belongs to those countries that are very bankoriented. We could conclude that traditional financial services offered by banks still dominate in Serbia. 
Further in the paper we will present findings from our case study, considering financial services performance in Serbia.

\section{Literature review}

One of the goals of this study is to analyze how well people in Serbia are informed about opportunities in the market and how they make financial decisions. More precisely, we focused on financial literacy. Financial literacy can be defined as people's ability to process and make informed decisions about financial planning, wealth management, investments, pension plans and loans. Remund (2010) argues that "financial literacy is a measure of the degree to which one understands key financial concepts and possesses the ability and confidence to manage personal finances through appropriate short-term decision-making and sound, long-range financial planning." Moreover, financial literacy measures how well people understand and use personal finance-related information (Huston, 2010).

Although financial literacy is one of the crucial elements of responsible and controlled financial behavior, it does not guarantee appropriate and profitable financial decisions. The success of financial decisions depends not only on financial literacy but also on impulsiveness, behavioral biases, unusual preferences and numerous external circumstances (Huston, 2010).

The conventional economic approach suggests that people are fully rational, wellinformed and that they will always make optimal decisions. This means that people will be able to save money and take responsibilities in terms of their investments. The truth is that this approach is far from reality. Generally speaking, people do not have basic financial knowledge which is very important for making complex financial decisions.

Nowadays financial decisions are very personalized, and people should be very careful in order to organize their finances in the best possible way. On the contrary, in the past, financial decisions (e.g. pension plans, savings, investments etc.) were initiated and managed by governments and companies. Employees devoted little attention to their financial decisions, especially to pension plans (Fernandes et al., 2014). The reason for this is low level of education in terms of financial opportunities and optimal investments or savings plans. There is an ongoing discussion on how to accumulate financial knowledge early in life even if there is no opportunity for complex financial decisions thereafter.

On the one hand, financial literacy has many advantages. For instance, people with strong financial skills have better results in job planning and savings (Lusardi \& Mitchell, 2014). Risk awareness is one of the characteristics of financially savvy investors who always try to invest in several ventures and diversify financial risks (Abreu \& Mendes, 2010). On the other hand, financial ignorance comes with significant costs. People who do not understand basic financial concepts usually have problems with higher interest rates and transaction fees (Lusardi \& Tufano, 2015). Additionally, they borrow more and save less money (Stango \& Zinman, 2009). Finally, Huston (2010) summarizes: "people with low financial literacy are more likely to have problems with debt (Lusardi \& Tufano 2009), less likely to participate in the stock market (van Rooij et al., 2011), less likely to choose mutual 
funds with lower fees (Hastings \& Tejeda-Ashton, 2008), less likely to accumulate wealth and manage wealth effectively (Hilgert et al., 2003) and less likely to plan for retirement (Lusardi \& Mitchell, 2006)".

Different research studies on financial literacy have shown that numerous people all around the world are financially illiterate (Hilgert et al., 2003). The study shows that one out of three adults is financially literate. Women, the poor and lower educated respondents show the lowest level of financial literacy, and the results remain the same regardless of the development of the country. People who use different financial services have better financial skills. Therefore, financial knowledge is related to financial services in two directions: higher financial literacy lead to the usage of financial services, and different financial services, such as a bank account or loan, motivate people to improve their financial knowledge. Nevertheless, there is a view that financial literacy is not linked to simple decisions such as having a bank account but rather to complex portfolio decisions which come with high levels of risk (Christelis et al., 2010). On the other hand, Hilgert et al. (2003) point out that there is a strong correlation between financial literacy and day-today financial management skills. Results from different studies show that people who are better at solving mathematical problems and who are financially literate are also more likely to participate in financial markets and invest in different financial instruments (Christelis et al., 2010; van Rooij et al., 2011). In terms of complex financial decisions, what matters most are analytical skills and the capacity to do calculations (Hilgert et al., 2003).

In terms of financial education programs there are two streams of research. Some researchers suggest that costs of financial education programs are higher than the potential benefits (Mandell \& Klein, 2009). On the other hand, there is evidence that education programs are highly effective because they lead to optimal financial plans and, therefore, to positive financial outcomes (Fox et al., 2005).

Numerous studies suggest positive relationship between the level of education and financial literacy and emphasize differences in financial knowledge through education. People with college degrees, in comparison to those who did not continue formal education after high school, are more likely to use financial instruments in order to make better financial decisions (Lusardi \& Mitchell, 2007). In addition, it has been shown that financial literacy depends on the financial education of their parents. It might be beneficial for children to be aware of their parents' savings and investments (Lusardi et al., 2010).

In the wake of the global financial crisis, policy makers and people from the financial industry show deep concern about financial literacy especially in youth. Younger generations have much more opportunities such as exotic mortgage forms, expended and new borrowing options and investments in innovative solutions tightly linked to technological development. Moreover, new generations have a very strong desire to be successful, to have freedom and flexibility. They have high self-esteem and expectations which are used as the main drivers of change. Moreover, the value of money, risk averseness and motivation for success influence the use of financial services especially for youth. Nga et al. (2010) point out that the lack of financial awareness in financial services 
and products is present within new generations. In the past, people used to be savvy, better educated and prepared to take higher risk.

Not many studies analyze the awareness of financial products and services, especially in emerging countries such as Serbia. Complexity of transactions in the underdeveloped financial markets and lack of transparency lead to lower levels of trust and financial awareness. Boyd et al. (1994) argue that low-income families do not have enough experience or knowledge to choose the best possible financial options. Results show that low-income families rely solely on word of mouth when they have to make any financial decision. Contrary, high-income families are focused on interest rates and savings accounts and emphasize the importance of the friendly approach of financial experts.

The study implies that there is room for improvement in terms of financial awareness in Serbia. Financial institutions should have a proactive and socially responsible role. Boyd et al. (1994) argue that the reputation of financial institutions, clear and direct communication in terms of interest rates on loans and savings, and availability of information have more importance than other criteria. Not only is financial literacy important for individuals but also for the sector of small and medium enterprises and corporate world (Drexler et al., 2014).

\section{Sample and procedure}

This survey tests financial service awareness in Serbia. A questionnaire was developed, and pilot tested before the formal data collection. The questionnaire comprises two parts with 10 questions totally. The first part of the questionnaire refers to demographic review of the respondents. It consists of questions regarding gender, age, marital status, housing issue and education. The second part encompasses questions regarding respondent's financial services awareness in Serbia. After the question concerning working in private or public institution, the remaining questions in this part refer to income, types of financial services currently or previously used, and awareness of different types of financial services in Serbia, as well as perception of less or not using the financial services in Serbia. Whenever possible, measurement items were adapted from existing scales in literature. Some modifications were made to align the scales with the Serbian context. The response rate was $62 \%$, corresponding to a sample size of 217 cases out of the 350 questionnaires successfully sent out using Google Forms.

\section{Results}

The financial services awareness scale was created using the five-point Likert-type scale that ranges from 1 (totally unaware) to 5 (totally aware). The question components for the construct of the scale, as well as its descriptive statistics, are listed in Table 1. The Cronbach alpha coefficient is 0.916 which points to an excellent internal consistency of a scale. 
Table 1: Financial services awareness scale descriptive statistics and its components

\begin{tabular}{ll}
\hline Scale & Financial services awareness \\
\hline Min & 5 \\
Max & 25 \\
Average & 13.37 \\
SD & 5.669 \\
Median & 13 \\
\hline Cronbach alpha & 0.916 \\
Components & 1. Insurance companies \\
& 2. Investment funds \\
& 3. Voluntary pension funds \\
& 4. Belgrade Stock Exchange \\
& 5. Bonds \\
\hline
\end{tabular}

Source: the authors' research

The following table gives the results of Kendall's tau correlation test, which is used to test the correlations among ordinal scaled data.

Table 2: Kendall's tau correlation coefficients for financial services awareness components

\begin{tabular}{lllll}
\hline & $\begin{array}{l}\text { Investment } \\
\text { funds }\end{array}$ & $\begin{array}{l}\text { Voluntary } \\
\text { pension funds }\end{array}$ & $\begin{array}{l}\text { Belgrade Stock } \\
\text { Exchange }\end{array}$ & Bonds \\
\hline Insurance companies & $0.597^{* * *}$ & $0.622^{* * *}$ & $0.493^{* * *}$ & $0.475^{* * *}$ \\
Investment funds & & $0.620^{* * *}$ & $0.617^{* * *}$ & $0.623^{* * *}$ \\
Voluntary pension funds & & & $0.542^{* * *}$ & $0.545^{* * *}$ \\
Belgrade Stock Exchange & & & & $0.862^{* * *}$ \\
\hline
\end{tabular}

$* \mathrm{p}<0.05 * * \mathrm{p}<0.01 * * * \mathrm{p}<0.001$

Source: the authors' research

All correlations are significant on a 0.001 level. The values indicate middle to strong concordance among financial services awareness components. The correlations between Insurance companies and Belgrade Stock Exchange awareness (0.493) and between Insurance companies and Bonds awareness (0.475), as well as between Voluntary pension funds and Belgrade Stock Exchange awareness (0.542) and between Voluntary pension funds and Bonds awareness (0.545) are of middle strength, while others are strong correlations. The strongest concordance appears between Belgrade Stock Exchange and Bonds awareness (0.862).

Table 3 gives the results of Mann-Whitney and Kruskall-Wallis tests for the scale Financial services awareness. The nonparametric tests were used since the variable is not normally distributed.

According to the results given in Table 3, there is a significant difference between men and women regarding the financial services awareness in Serbia (MW, $<<0.001)$. Men $(\mathrm{Me}=15)$ are generally more aware and more familiar with the financial services than Women $(\mathrm{Me}=10)$. 
Table 3: The results of Mann-Whitney and Kruskall-Wallis tests for Financial services awareness

\begin{tabular}{lllc}
\hline Groups by & \multicolumn{4}{l}{ Financial services awareness } & \\
\hline Gender & Mean rank & Median & Mann-Whitney Sig. \\
\hline Male & 125.88 & 15 & $<0.001$ \\
Female & 95.61 & 10 & \\
\hline Salaries (RSD) & Mean rank & Median & Kruskall-Wallis Sig. \\
\hline less than 35000 & 88.64 & 10 & 0.003 \\
$35000-55000$ & 90.03 & 10 & \\
$55000-75000$ & 106.86 & 13 & \\
$75000-100000$ & 100.81 & 13 & \\
more than 100000 & 128.88 & 15 & \\
\hline
\end{tabular}

Source: the authors' research

When it comes to salaries, people that make less than 55,000 RSD a month are the least aware about the possibilities of financial services in Serbia $(\mathrm{Me}=10)$. People that make 55,000 to $100,000 \mathrm{RSD}$ are a bit more familiar with the financial services $(\mathrm{Me}=13)$, while people that make more than 100000 are the most familiar with the financial services in Serbia $(\mathrm{Me}=15)$. This difference is significant on 0.01 level $(\mathrm{KW}, \mathrm{p}=0.003)$. The explanation could be given in a fact that people that make most money are more frequently contacted by the bank operators and informed about the possibilities of these services. Ironically, they most commonly do not use these services because of their lack of interest (Table 4).

Table 4: Crosstabs Salaries * Reasons for not using financial services

\begin{tabular}{llllll}
\hline & $\begin{array}{l}\text { Lack of } \\
\text { awareness }\end{array}$ & Indifference & Distrust & $\begin{array}{l}\text { Lack of } \\
\text { finances }\end{array}$ & Other \\
\hline less than $\mathbf{3 5 0 0 0}$ & $23.8 \%$ & $9.5 \%$ & $4.8 \%$ & $52.4 \%$ & $9.5 \%$ \\
$\mathbf{3 5 0 0 0}-\mathbf{5 5 0 0 0}$ & $25.0 \%$ & $30.8 \%$ & $23.1 \%$ & $19.2 \%$ & $1.9 \%$ \\
$\mathbf{5 5 0 0 0}-\mathbf{7 5 0 0 0}$ & $28.0 \%$ & $20.0 \%$ & $32.0 \%$ & $20.0 \%$ & $0.0 \%$ \\
$\mathbf{7 5 0 0 0}-\mathbf{1 0 0 0 0 0}$ & $18.8 \%$ & $28.1 \%$ & $28.1 \%$ & $15.6 \%$ & $9.4 \%$ \\
more than 100 000 & $16.1 \%$ & $43.7 \%$ & $16.1 \%$ & $11.5 \%$ & $12.6 \%$ \\
\hline
\end{tabular}

Source: the authors' research

According to the crosstabs results, there is a concordance between the amount of money that people make and reasons for not using financial services in Serbia. The value of Crosstabs Likelihood Ratio test is 39.551 , and is significant on 0.001 level $(p=0.001)$. It can be noted from Table 4 that people that make least amount of money mostly do not use financial services because of the lack of finances. People that earn medium amounts of money in Serbia mostly do not use financial services because of distrust in the financial system, while people that make the most money are simply indifferent and not interested in these services.

\section{Conclusion}

Financial services industry is perceived as one of the main drivers of a country's economy. Being equally important to both companies and individuals, financial services industry has always drawn a lot of attention, from possible investors, those who need financing, 
government and general public. Globally, financial opportunities are becoming more diverse, attractive and, on the other hand, more complex.

In this paper we start from the hypothesis that financial education and literacy are preconditions for the use of financial opportunities. Generally speaking, financial literacy leads to optimal decision making about borrowing money, investments, pension plans, participation in the financial markets etc. This study aims to provide an overview of the use of financial services in Serbia in order to improve financial decision-making processes and understand the different financial opportunities.

Not many studies analyze the awareness of financial products and services, especially in emerging countries such as Serbia. Underdeveloped financial markets and lack of transparency lead to lower levels of trust and financial awareness in markets like Serbia.

Survey results show that the amount of money that people make and reasons for not using financial services in Serbia are very much in concordance. Our results show that people with salaries higher than 100,000 RSD (app. 850€) are well informed but not motivated to invest. Individuals with middle income do not have enough trust and think that they are not well informed about different opportunities. People that make the least money mostly do not use financial services because of the lack of finance. Additionally, we found that men are more informed than women.

This study indicates that there is possibility for improvement in terms of financial awareness in Serbia. Having in mind that financial services industry is a motor for the economy, it is essential for the financial institutions to understand and to play a proactive and socially responsible role. Together with the regulators they should work on financial literacy and education, from early stage of education and on creating trust in financial services industry in Serbia.

\section{References}

Abreu, M., \& Mendes, V. (2010). Financial literacy and portfolio diversification. Quantitative finance, 10(5), 515-528. Doi: https://doi.org/10.1080/14697680902878105

Boyd, W. L., Leonard, M., \& White, C. (1994). Customer preferences for financial services: an analysis. International Journal of Bank Marketing, 12(1), 9-15.

Christelis, D., Jappelli, T., \& Padula, M. (2010). Cognitive abilities and portfolio choice. European Economic Review, 54(1), 18-38.

Drexler, A., Fischer, G., \& Schoar, A. (2014). Keeping it simple: Financial literacy and rules of thumb. American Economic Journal: Applied Economics, 6(2), 1-31. Doi: https://doi.org/10.1257/app.6.2.1

Fernandes, D., Lynch Jr., J. G., \& Netemeyer, R. G. (2014). Financial literacy, financial education, and downstream financial behaviors. Management Science, 60(8), 1861-1883. Doi: https://doi.org/10.1287/mnsc.2013.1849

Fox, J., Bartholomae, S., \& Lee, J. (2005). Building the case for financial 
education. Journal of consumer affairs, 39(1), 195-214. Doi: https://doi.org/10.1111/j.1745-6606.2005.00009.x

Hastings, J. S., \& Tejeda-Ashton, L. (2008). Financial literacy, information, and demand elasticity: Survey and experimental evidence from Mexico (No. w14538). National Bureau of Economic Research. Doi: https://doi.org/10.3386/w14538

Hilgert, M. A., Hogarth, J. M., \& Beverly, S. G. (2003). Household financial management: The connection between knowledge and behavior. Fed. Res. Bull., 89, 309-322.

Huston, S. J. (2010). Measuring financial literacy. Journal of Consumer Affairs, 44(2), 296316. Doi: https://doi.org/10.1111/j.1745-6606.2010.01170.x

Lusardi, A., \& Mitchel, S. O. (2006). Financial Literacy and Planning: Implications for Retirement Wellbeing(Vol. 1). Pension Research Council Working Paper. Doi: https://doi.org/10.2139/ssrn.1695146

Lusardi, A., \& Mitchell, O. S. (2014). The economic importance of financial literacy: Theory and evidence. Journal of economic literature, 52(1), 5-44. Doi: 10.1257/jel.52.1.5

Lusardi, A., \& Tufano, P. (2015). Debt literacy, financial experiences, and overindebtedness. Journal of Pension Economics \& Finance, 14(4), 332-368. Doi: https://doi.org/10.1017/S1474747215000232

Lusardi, A., Mitchell, O. S., \& Curto, V. (2010). Financial literacy among the young. Journal of consumer affairs, 44(2), 358-380. Doi: https://doi.org/10.1111/j.1745$\underline{6606.2010 .01173 . \mathrm{x}}$

Mandell, L., \& Klein, L. S. (2009). The impact of financial literacy education on subsequent financial behavior. Journal of Financial Counseling and Planning, 20(1), 1524.

National Bank of Serbia. (2019). Annual reports of banks for 2019. Retrieved July 5, 2021, from https://www.nbs.rs/export/sites/NBS site/documents-eng/kontrola banaka/quarter report IV 19.pdf

National Bank of Serbia. (2019). Annual reports of insurance companies for 2019. Retrieved July 5, 2021, from https://www.nbs.rs/export/sites/NBS site/documentseng/osiguranje/izvestaji/insurance_IV_2019.pdf

National Bank of Serbia. (2019). Annual reports of leasing for 2019 respectively. Retrieved July 5, 2021, from https://www.nbs.rs/export/sites/NBS site/documentseng/lizing/izvestaji/FL_IV 2019.pdf

National Bank of Serbia. (2019). Annual reports of voluntary pension funds for 2019. Retrieved July 5, 2021, from https://www.nbs.rs/export/sites/NBS site/documentseng/dpf/izvestaji/vpf IV 19.pdf

Nga, J. K., Yong, L. H., \& Sellappan, R. D. (2010).

A study of financial awareness among youths. Young Consumers, 11(4), 277-290. Doi:

https://doi.org/10.1108/17473611011093916 
Remund, D. L. (2010). Financial literacy explicated: The case for a clearer definition in an increasingly complex economy. Journal of Consumer Affairs, 44(2), 276-295. Doi: https://doi.org/10.1111/j.1745-6606.2010.01169.x

Republic of Serbia Securities Commission. (2019). Annual Activity Report 2019. Retrieved July 5, 2021, from https://www.sec.gov.rs/index.php/en/about-us/internaldocuments/commission-reports (Serbian version).

Stango, V., \& Zinman, J. (2009). Exponential growth bias and household finance. The Journal of Finance, 64(6), 2807-2849. Doi: https://doi.org/10.1111/j.15406261.2009.01518.x

Van Rooij, M., Lusardi, A., \& Alessie, R. (2011). Financial literacy and stock market participation. Journal of Financial Economics, 101(2), 449-472. Doi: https://doi.org/10.1016/j.jfineco.2011.03.006

World Economic Forum. (2015). The Future of Financial Services; How disruptive innovations are reshaping the way financial services are structured, provisioned and consumed. p. 13. Retrieved July 2, 2021, from Doi: http://www3.weforum.org/docs/WEF_The future_of_financial_services.pdf 